Roos, Djoni. As lutas camponesas no Estado do Paraná e os modelos da "Reforma Agrária" brasileira. GeoGrahos. [En línea]. Alicante: Grupo Interdisciplinario de Estudios Críticos y de América Latina (GIECRYAL) de la Universidad de Alicante, 2 de enero de 2013, vol. 4, n 31, p. 1-18. [ISSN: 21731276].

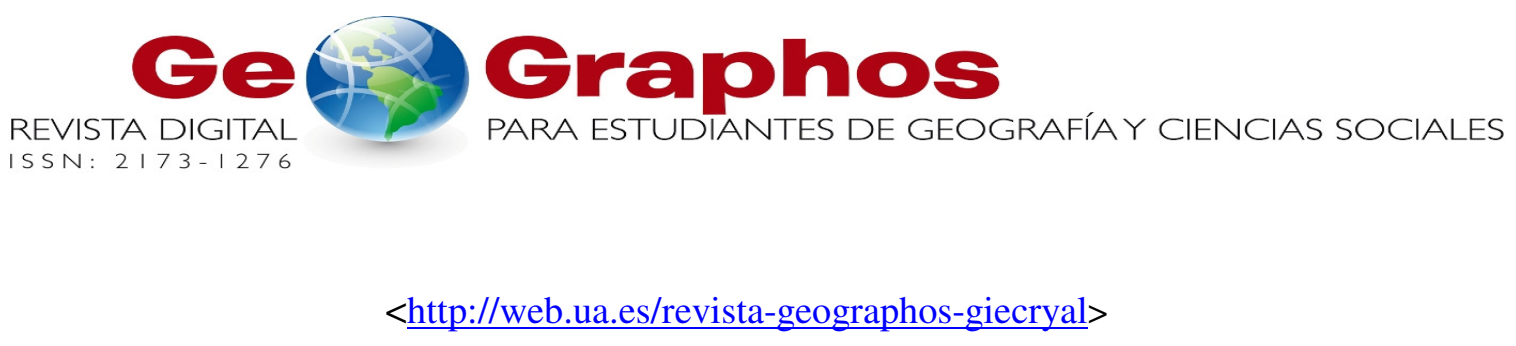

Vol. 4. No 31

Año 2013

\title{
AS LUTAS CAMPONESAS NO ESTADO DO PARANÁ E OS MODELOS DA “REFORMA AGRÁRIA” BRASILEIRA ${ }^{1}$
}

\author{
Djoni Roos \\ Doutorando em Geografia \\ Programa de Pós-Graduação em Geografia da Universidade Estadual Paulista - UNESP \\ Faculdade de Ciências e Tecnologia de Presidente Prudente - FCT \\ Pesquisador do Núcleo de Estudos Pesquisas e Projetos de Reforma Agrária - \\ NERA/FCT/UNESP e do Grupo de Pesquisa de Geografia das Lutas no Campo e na \\ Cidade GEOLUTAS/UNIOESTE/Mal. C. Rondon/PR \\ Presidente Prudente, São Paulo, Brasil \\ Correio eletrônico: djoni_roos@yahoo.com.br
}

Recibido: 7 de agosto de 2012. Aceptado: 2 de enero de 2013

\section{RESUMO}

O presente texto visa evidenciar que é somente através do enfrentamento que os camponeses têm garantido o seu espaço no estado do Paraná, destacando os assentamentos rurais como importantes conquistas camponesas. Para tanto, apresentamse as principais lutas ocorridas no campo paranaense, enfatizando a relação com o Estado em determinados períodos de governo e denunciando a violência, seja de milícias privadas ou de forças policiais, com que as lutas camponesas são tratadas. Outro propósito do artigo é expor os modelos de "reforma agrária" adotados no Brasil, a

\footnotetext{
${ }^{1}$ Este texto tem como base as reflexões iniciais de nossa Tese de Doutorado em andamento. Trabalho desenvolvido com auxílio (bolsa de doutorado) da Coordenação de Aperfeiçoamento de Pessoal de Nível Superior-CAPES.
} 
fim de ratificar que a "reforma agrária" realizada tanto no campo paranaense, quanto brasileiro, é a partir da luta e enfrentamento dos camponeses.

Palavras-Chave: Lutas Camponesas, Assentamentos Rurais, Reforma Agrária, Paraná, Latifúndio.

\title{
LAS LUCHAS CAMPESINAS EN EL ESTADO DE PARANÁ Y MODELOS DE LA "REFORMA AGRARIA" BRASILEÑA
}

\section{RESUMEN}

Este trabajo pretende demostrar que es sólo a través de la confrontación que los campesinos han asegurado su lugar en el estado de Paraná, destacando los asentamientos rurales como importantes logros de los campesinos. Para ello, presentamos las principales luchas se produjeron en el campo de Paraná, haciendo hincapié en la relación con el Estado en ciertos períodos del gobierno y denunciando la violencia, ya sea de las milicias privadas o fuerzas policiales, que las luchas campesinas son tratados. Otro propósito de este artículo es presentar los modelos de "reforma agraria" adoptadas en Brasil con el fin de ratificar que la "reforma agraria" llevada a cabo tanto en el ámbito de Paraná, el Brasil es de la lucha y de la confrontación de los campesinos.

Palabras Clave: Luchas Campesinas, Asentamientos Rurales, Reforma Agraria, Paraná, Latifundio.

\section{THE PEASANT STRUGGLES IN THE STATE PARANÁ AND THE MODELS OF "LAND REFORM" BRAZILIAN}

\begin{abstract}
This paper aims to show that it is only through confrontation that peasants have secured their place in the state of Paraná, especially the rural settlements as important achievements peasant. To this end, we present the main struggles occurred in the field of Paraná, emphasizing the relationship with the State in certain periods of the government and denouncing the violence, whether of private militias or police forces, with the peasant struggles are treated. Another purpose of the article is to present models of "land reform" policies adopted in Brazil in order to ratify the "land reform" carried out both in the field of Paraná, the Brazilian is from the peasants' struggle and confrontation.
\end{abstract}

Keywords: Peasant Struggles, Rural Settlements, Agrarian Reform, Paraná, Latifundium. 


\section{INTRODUÇÃO}

Um dos objetivos deste ensaio é apresentar as principais lutas ocorridas no campo paranaense, enfatizando a relação com o Estado em determinados períodos de governo, destacando os assentamentos rurais como conquistas dos camponeses no Paraná. O intento é evidenciar que somente através do enfrentamento que os camponeses tem garantido o seu espaço no estado e que as lutas camponesas foram violentamente combatidas, seja por milícias privadas ou pelas forças policiais.

Outro propósito do texto é expor os modelos de "reforma agrária" adotados no Brasil. Procuramos pontuar desde as propostas realizadas antes do período ditatorial, durante a ditadura e os que surgiram posteriormente, como o I Plano Nacional de Reforma Agrária (PNRA), a reforma agrária de mercado e o II PNRA. A discussão em torno dos modelos de "reforma agrária" no campo brasileiro está diretamente relacionada com as lutas, conflitos e resistências dos camponeses no Paraná, pois, neste estado, os projetos de assentamentos estaduais são inexpressivos ${ }^{2}$ e a maioria dos assentamentos foram criados a partir de decretos federais.

Por fim, a ideia central do presente texto é demonstrar que a "reforma agrária" realizada tanto no campo paranaense, quanto brasileiro, é a partir da luta e enfrentamento dos camponeses. O Estado brasileiro nunca pautou uma política de reforma agrária, não democratizou o acesso a terra e não criou condições, para que os camponeses que a terra chegassem, pudessem colocá-la para produzir.

Para alcançar os objetivos propostos, compreende-se que é necessário expor o entendimento de Estado. Ao considerar que Estado não é um termo auto-explicativo, mas que envolve uma complexidade de relações, partilhamos do entendimento de Pereira (2006) que baseado em Borón (1994) define Estado como sendo ao mesmo tempo:

a) um ator corporativo dotado de aparelhos burocráticos e administrativos; b) uma arena de luta pelo poder político na qual se definem projetos de organização e direção da sociedade; c) o representante dos interesses gerais da comunidade nacional; d) um pacto de dominação mediante o qual uma aliança de classe constrói um sistema hegemônico. (Pereira, 2006, p. 364, grifos do autor).

Nesse sentido, compreende-se que as repressões, violências, modelos de reforma agrária, bem como as resistências, lutas e enfrentamentos dos camponeses sem terra estão atrelados com as disputas travadas dentro do Estado e o pacto estabelecido para a governança do mesmo.

\footnotetext{
${ }^{2}$ Do total de 314 assentamentos rurais existentes no estado do Paraná, apenas 8 são projetos estaduais. Dentre estes 8 está, inclusive, o projeto da colônia Penal Tormenta de Cascavel.
} 


\section{LUTAS CAMPONESAS NO ESTADO DO PARANÁ}

A resistência do campesinato no Paraná está articulada a um conjunto de lutas realizadas no campo brasileiro desde um passado distante. Dentre as lutas que marcaram o início da organização camponesa no Paraná podemos citar a Guerrilha de Porecatu e a Revolta do Sudoeste.

Na década de 1950, o Norte do Paraná foi palco de intensos conflitos com a formação da chamada "Guerrilha de Porecatu", quando os camponeses-posseiros se armaram para manter as terras devolutas de Jaguapitã e Porecatu sob seu domínio e posse, pois o governo do estado havia repassado a grandes proprietários rurais.

Ainda na década de 1950, o Sudoeste paranaense foi igualmente palco de intensos conflitos. As lutas surgiram quando os camponeses foram expulsos de suas terras pela manobra empreendida pelo governo do estado, que concedeu as terras a uma empresa colonizadora. Organizados em "assembleias gerais do povo" e "juntas governativas", os camponeses avançaram para a cidade de Francisco Beltrão, expulsaram as autoridades constituídas, tomaram a estação de rádio da cidade e garantiram a posse das suas terras.

No final da década de 1970, o Oeste constituiu-se noutra região de lutas no Paraná, principalmente com a mobilização e organização dos agricultores expropriados pela construção da barragem da Usina Hidrelétrica de Itaipu. Organizados na Comissão Pastoral da Terra (CPT) e em alguns Sindicatos de Trabalhadores Rurais (STRs) os camponeses expulsos e expropriados formaram o Movimento Justiça e Terra, que reivindicava a justa indenização das terras alagadas pelo reservatório da Itaipu.

A experiência das lutas contra a Itaipu no Oeste paranaense foi a base para o surgimento do Movimento dos Agricultores Sem-Terra do Oeste do Paraná (MASTRO), em 1981. Entre estes camponeses, encontravam-se arrendatários e posseiros "sem direito" à indenização da Itaipu. Enquanto no Movimento Justiça e Terra os camponeses lutavam para garantir a posse e indenização das terras, no MASTRO, a luta dos sem-terra passou a ser pela realização da reforma agrária.

Em 1983, surgiram outros movimentos de sem-terra no Paraná como o Movimento dos Agricultores Sem Terra do Litoral (MASTEL), Movimento dos Agricultores Sem Terra do Centro Oeste (MASTRECO), Movimento dos Agricultores Sem Terra do Norte do Paraná (MASTEN) e o Movimento dos Agricultores Sem-Terra do Sudoeste do Paraná (MASTES). Este último organizou-se, principalmente, com o apoio da CPT e da Associação de Estudos, Orientação e Assistência Rural (ASSESOAR).

Essa organização em diversos movimentos de luta pela terra, surgida no final da década de 1970 e início de 1980 no estado do Paraná, representa o quadro que existia no campo brasileiro, ou seja, vários movimentos estabelecidos regionalmente com pouca comunicação entre eles. No entanto, é necessário salientar que embora "isolados", estes movimentos contaram com o apoio da CPT, criada em 1975 para colaborar na defesa e organização das lutas camponesas. As diversas frentes de lutas que estavam ocorrendo acabaram por resultar primeiramente num encontro entre as lideranças dos cinco estados 
ao sul do Brasil (Paraná, Rio Grande do Sul, Santa Catarina, São Paulo e Mato Grosso do Sul) na cidade de Medianeira/PR no ano de 1982.

Os encontros de representantes tinham por objetivo criar uma articulação entre as diversas lutas que vinham ocorrendo no país. Em 1984, realizou-se na cidade de Cascavel no estado do Paraná o primeiro encontro de caráter nacional dos camponeses organizados nestes movimentos regionais, com a participação de camponeses de vários estados. Neste encontro surgiu o Movimento dos Trabalhadores Rurais Sem Terra (MST), com a finalidade de unir as diversas frentes de lutas regionais que vinham ocorrendo em todo o território nacional.

Com o surgimento do MST, as lutas pela reforma agrária tomaram novos caminhos, desta vez com mais força. Devido à articulação, deixaram de ser localizadas e se expressaram encadeadas a nível nacional, fato que garantiu maior visibilidade para toda à sociedade das desigualdades e disputas travadas no campo brasileiro. Neste momento, os camponeses elegeram as ocupações de terras como a principal tática de luta para retorno a terra.

O MST se espacializou, realizando ações massivas com ocupações e acampamentos em latifúndios nos mais variados municípios paranaenses. A resposta dos ruralistas foi imediata e violenta. Diversos camponeses Sem Terra foram assassinados por pistoleiros a mando dos latifundiários paranaenses.

Em meados da década de 1990 a violência contra a luta pela terra e reforma agrária no Paraná se acentuou. Em 1994, com a posse de Jaime Lerner (Partido da Frente Liberal PFL, atualmente, Democratas - DEM) no governo estadual, adotaram-se severas políticas de combate aos movimentos sociais. Verifica-se neste momento, um claro "pacto de dominação" no governo do estado. Jaime Lerner representava a vanguarda do projeto neoliberal no estado, possuindo estreitas alianças com latifundiários, transnacionais, banqueiros e empresários do agronegócio. Durante seu mandato, o governador impediu a realização de manifestações nas grandes cidades do estado, interviu em decisões e desapropriações do Instituto Nacional de Colonização e Reforma Agrária (INCRA) e, sobretudo, ordenou à polícia militar o cumprimento imediato das reintegrações de posse, as quais ficaram marcadas pela violência dos despejos realizados geralmente no período da madrugada.

O período em que Jaime Lerner esteve no governo do Paraná (1994-2002) foi, sobretudo, um tempo de extrema violência no campo do estado. Entre 1994 a 2002 foram contabilizados, no Paraná, 16 assassinatos de camponeses, 49 ameaças de morte e 325 feridos, em 134 ações de despejo, realizadas tanto pela polícia militar estadual, quanto por milícias privadas ligadas às entidades patronais (CPT/PR, 2006).

Os conflitos agrários no Paraná, durante o governo Lerner, foram tratados como caso de polícia em verdadeiras "operações de guerra" e não como problema social. Durante este período, a polícia militar do Paraná mantinha um centro para treinar, doutrinar ideologicamente e orientar os soldados no combate aos movimentos sociais. Os despejos realizados pela polícia estadual, durante a madrugada, tornaram-se frequentes e aconteceram diante flagrantes violações dos direitos humanos e constitucionais. Os 
despejos dos camponeses ocupantes eram precedidos de mandatos de reintegração de posse expedidos por juízes atrelados aos ruralistas paranaenses.

As ações da polícia militar do Paraná para combater os Sem Terra eram acompanhadas de perto pelas entidades patronais como a União Democrática Ruralista (UDR), sindicatos patronais e Sociedades Rurais regionais que davam apoio logístico a estas atividades, numa clara demonstração do "pacto de dominação" estabelecido no estado. As milícias privadas dos ruralistas, também atuavam livremente pelo campo paranaense, participando e realizando despejos por conta própria, ameaçando, torturando e assassinando camponeses Sem Terra. Diante de tudo isso a impunidade prevaleceu e a grande maioria dos assassinatos dos camponeses, sequer foi julgada pelo Estado.

Ante aos fatos explicitados questiona-se: a serviço de quem está o Estado? Nos casos relatados houve uma clara demonstração que o Estado serviu para manter a inviolabilidade da propriedade privada capitalista em oposição a democratização da terra. Contudo, mesmo perante a repressão sofrida no governo Lerner, os camponeses continuaram lutando e entre as conquistas mais representativas deste período está a criação, em 1997, dos assentamentos Ireno Alves dos Santos (900 famílias) e Marcos Freire (604 famílias), ambos no município de Rio Bonito do Iguaçu. Os referidos assentamentos foram conquistados a partir da ocupação do latifúndio da GiacometMarodin ${ }^{3}$, em 1996.

Com a mudança de governo no Paraná e a posse de Roberto Requião (Partido do Movimento Democrático Brasileiro - PMDB), em 2003, houve uma modificação na "arena" política estadual, fato que aumentou as expectativas dos trabalhadores rurais ${ }^{4}$ que realizaram, logo no primeiro mês, diversas ocupações de terra. Este crescimento da luta pela terra veio acompanhado da reação das camadas latifundiárias do Paraná, que criaram em março de 2003, o Primeiro Comando Rural (PCR). O PCR foi criado com o intuito de agenciar pistoleiros para combater as ocupações de terra e agiu principalmente na região Central do estado.

A violência contra os trabalhadores rurais Sem Terra continuou no Paraná. A mudança neste período foi que o governador Roberto Requião, passou a não cumprir grande parte dos mandatos de reintegração de posse e principalmente não tratou os conflitos agrários como caso de polícia. A atitude do governador causou revolta entre os latifundiários, que juntamente com suas milícias armadas passaram a executar os despejos.

Ação emblemática deste período foi a ocupação da área experimental da Syngenta em Santa Tereza do Oeste. Neste ato, o governo do estado permaneceu ao lado dos camponeses ligados a Via Campesina, pautando a desapropriação da área (na qual se realizavam pesquisas com transgênicos) e a transformação da mesma num centro de pesquisas agroecológicas.

Perante a atitude do governo do estado, os ruralistas se manifestaram. O então Presidente da Sociedade Rural do Oeste (SRO) Alessandro Meneghel, afirmou que:

\footnotetext{
${ }^{3}$ Em 1997 a empresa mudou sua denominação para Araupel S. A.

${ }^{4}$ É importante lembrar que neste mesmo período Luís Inácio Lula da Silva foi eleito presidente do Brasil.
} 
"Não vamos mais aceitar invasões. Se o governo não cumprir as reintegrações, nós vamos fazer com as nossas próprias mãos" (Confronto.., 2006, p. 9). Após várias ocupações e mandatos de reintegração de posse, em outubro de 2007, uma milícia armada a serviço da SRO e do Movimento dos Produtores Rurais (MPR) ${ }^{5}$, com 40 homens fortemente armados, tentou despejar os camponeses da área da Syngenta. Neste violento confronto foi assassinado o trabalhador rural Valmir Mota de Oliveira (Keno), liderança do MST na região Oeste do Paraná.

Perante os fatos apresentados dos dois últimos períodos de governo do estado do Paraná (Jaime Lerner e Roberto Requião), procurou-se demonstrar o Estado enquanto um "ator corporativo" e principalmente, como uma "arena" de luta pelo poder político. O Estado enquanto uma arena de disputa ficou visível nas ações diferenciadas tomadas pelos dois governos para com a luta pela terra no Paraná. Enquanto que um governo, extremamente atrelado a setores conservadores da sociedade, estabeleceu como princípio a criminalização da luta pela terra e o seu tratamento com violência, o outro, buscou uma aproximação e diálogo com os movimentos sociais do campo, optando em muitos casos pela defesa dos camponeses perante a ação dos ruralistas. Frisa-se que a intenção não é defender este ou aquele governo, mas demonstrar como em determinados períodos ocorreram disputas dentro do Estado e como estas afetaram os camponeses Sem Terra.

Na última década, no estado do Paraná, as ocupações de terra tem se destacado dentre as diferentes lutas camponesas realizadas. Analisando a tabela 1, verifica-se que no período de 2000 a 2010 foram realizadas 285 ocupações, mobilizando 51.517 famílias no estado. Estas ocupações ocorreram principalmente, pela organização dos camponeses no MST. É importante ressaltar que embora o MST tenha sido o movimento mais ativo, no Paraná existem diversas outras organizações camponesas atuantes. Marques (2008) identificou que no período compreendido entre 1988 e 2006, ocorreram 682 ocupações de terra no Paraná, as quais foram realizadas por 19 movimentos sociais diferentes.

Tabela 1. Ocupações de terras realizadas pelos movimentos camponeses no Paraná. Anos 2000-2010

\begin{tabular}{c|c|c|c|c|c|c|c|c|c|c|c}
\hline \multicolumn{2}{c|}{ MST } & \multicolumn{2}{c|}{ CONTAG } & \multicolumn{2}{c|}{ MLST } & \multicolumn{2}{c|}{ Outros } & \multicolumn{2}{c}{ N. I. } & \multicolumn{2}{c}{ TOTAL } \\
\hline Ocup & Fam & Ocup & Fam & Ocup & Fam & Ocup & Fam & Ocup & Fam & Ocup & Fam \\
\hline 183 & 32.709 & 18 & 946 & 3 & 270 & 43 & 9.494 & 33 & 8.098 & 285 & 51.517 \\
\hline
\end{tabular}

Fonte: Dataluta. Org.: Autor.

* Não Informado.

As várias lutas realizadas no Paraná resultaram na criação de 310 assentamentos rurais, onde se encontram 17.849 famílias numa área de 393.232,0287 ha. A distribuição dos assentamentos e do número de famílias por mesorregião pode ser observada na tabela 2 .

\footnotetext{
${ }^{5}$ Empresa NF Segurança.
} 
Tabela 2. Número de assentamentos, famílias e área no Paraná. Anos 1979-2009

\begin{tabular}{|c|c|c|c|}
\hline MESORREGIÃO & ASSENTAMENTOS & FAMÍLIAS & ÁREA (ha) \\
\hline Noroeste & 35 & 1.819 & $46.692,1615$ \\
\hline Centro-Ocidental & 18 & 705 & $14.467,8399$ \\
\hline Norte-Central & 31 & 1.626 & $34.742,9776$ \\
\hline Norte Pioneiro & 26 & 1.198 & $24.657,8912$ \\
\hline Centro-Oriental & 30 & 1.454 & $34.027,0312$ \\
\hline Oeste & 26 & 1.432 & $34.651,3489$ \\
\hline Sudoeste Paranaense & 18 & 1.120 & $20.853,0976$ \\
\hline Centro-Sul & 104 & 7.361 & $153.244,9658$ \\
\hline Sudeste & 20 & 889 & $25.123,9500$ \\
\hline Metropolitana de Curitiba & 2 & 245 & $4.770,7650$ \\
\hline Total & $\mathbf{3 1 0}$ & $\mathbf{1 7 . 8 4 9}$ & $\mathbf{3 9 3 . 2 3 2 , 0 2 8 7}$ \\
\hline
\end{tabular}

Fonte: INCRA, 2009. Org.: Autor.

As conquistas dos assentamentos no Paraná são resultantes do enfrentamento camponês ao latifúndio e ao Estado e não de uma política de reforma agrária. É assim que o campesinato paranaense e brasileiro tem retomado a sua terra usurpada pelos setores dominantes da sociedade, ou seja, pelo enfrentamento, pela rebeldia à condição imposta.

A partir do apontamento de algumas lutas e conquistas camponesas no Paraná pretendese discorrer sobre os modelos de "reforma agrária" realizados no Brasil, pois a maioria dos assentamentos rurais conquistados no estado foi através de intervenções federais. Cabe pontuar que o Paraná, não possui órgão próprio com a função de criar assentamentos. O Instituto de Terras Cartografia e Geociências do Paraná (ITCG) possui funções de regularização fundiária, cadastro rural, etc., ou seja, não é destinado a desapropriação de terras e criação de assentamentos rurais.

\section{OS MODELOS DA “REFORMA AGRÁRIA” BRASILEIRA}

A luta dos movimentos camponeses, tanto no Paraná, quanto no Brasil tem como principal pauta de reivindicação a realização da reforma agrária. Mas, o que é reforma agrária? A reforma agrária consiste num conjunto de ações públicas, visando promover uma reordenação territorial, modificando a estrutura fundiária de um país através da distribuição da propriedade ou da posse da terra. O objetivo da reforma agrária é a democratização da estrutura fundiária (Pereira, 2006; Oliveira, 2007).

Dois são os pilares estruturais em que o Estado deve atuar para uma efetiva reforma agrária: política fundiária e agrícola. Na política fundiária está implícito um conjunto de medidas para definir um limite máximo e mínimo para a propriedade privada da terra. Com relação à política agrícola, estas são um conjunto de ações do Estado para garantir assistência técnica e social, fomento, educação, saúde, infraestrutura, etc. (Kay, 2007; Pereira, 2006; Oliveira, 2007).

Portanto, a reforma agrária não diz respeito apenas à distribuição de terra aos camponeses despossuídos, pois envolve mudanças na estrutura fundiária de um país e 
atendimento de um conjunto de demandas de natureza econômico-produtiva que se desdobram nas dimensões política, social e econômica.

No Brasil a reforma agrária não aparece como política de Estado. A reforma agrária foi colocada na pauta política brasileira pelos camponeses. Foi com as Ligas Camponesas, a partir de 1950, que a discussão em torno da reforma agrária apareceu no Brasil. A partir de então, as lutas camponesas adquiriram um novo conteúdo político, pois reforma agrária implica na distribuição equitativa da terra e em condições que garantam a reprodução social do campesinato.

Com esse novo conteúdo político as lutas camponesas no Brasil se acentuam. Em decorrência da tensão social existente no campo, houve no governo de João Goulart (1961-1964), do Partido Trabalhista Brasileiro (PTB), uma primeira tentativa de realização da reforma agrária. A criação da Superintendência de Política Agrária (SUPRA) em outubro de 1962 é um exemplo da tentativa de se estabelecer uma política de distribuição de terras. O principal objetivo da SUPRA, era colaborar na formulação de uma política agrária para o país, planejando e executando a reforma agrária, utilizando-se do recurso da desapropriação dentro da legislação em vigor. O governo Goulart pretendia promover a desapropriação por interesse social, com a finalidade de promover uma distribuição fundiária e condicionar o uso da terra ao bem estar social. Além disso, procurava aprovar no Congresso Nacional uma emenda constitucional para a reforma agrária na qual as desapropriações deveriam ser pagas com títulos da dívida pública.

A proposta da reforma agrária por emenda constitucional acabou sendo derrotada no Congresso em 1963, bem como, a desapropriação por interesse social. Diante disso, o governo Goulart tentou repassar aos camponeses, terras compreendidas num raio de 10 $\mathrm{km}$ da margem das rodovias e ferrovias federais e áreas rurais situadas nas bacias de irrigação pertencentes aos açudes públicos. Estas terras seriam repassadas por meio de decretos que as consideravam de interesse social para efeito de desapropriação. Através dessa medida o governo de Goulart procurava tornar produtivas áreas inexploradas ou submetidas à especulação. Essa proposta "mínima" de "reforma agrária" que em nada afetava a concentração da terra, esbarrou no Congresso Nacional que defendia os interesses dos proprietários de terra. Os latifundiários não queriam perder a valorização que as terras próximas de rodovias, ferrovias e açudes públicos tinham alcançado.

Em 1964 ocorreu o golpe militar, deposição de Goulart e o fim do projeto de reforma agrária do governo. As lutas também foram reprimidas. A militarização da questão agrária foi uma das formas utilizadas para conter as tensões sociais que estavam em ascendência. Outro instrumento utilizado foi à elaboração do Estatuto da Terra, baseado em um modelo desenvolvimentista. O Estatuto da Terra previa a classificação dos imóveis rurais em minifúndios, latifúndios por dimensão e exploração e em empresas rurais.

O latifúndio e o minifúndio, fontes geradoras dos conflitos, deveriam ser substituídos pela empresa rural. Considerado uma irracionalidade, o latifúndio seria substituído por uma exploração "racional", ou seja, a empresa rural capitalista. Esse modelo ideal de imóvel rural deveria cumprir a função social da terra determinada pela Constituição. 
A SUPRA foi eliminada e em seu lugar criado o Instituto Brasileiro de Reforma Agrária (IBRA) e o Instituto Nacional de Desenvolvimento Agrário (INDA). Estes dois órgãos se envolveram, posteriormente, em forte esquema de grilagem e venda de terras a estrangeiros.

Em 1970 nasceu o Instituto Nacional de Colonização e Reforma Agrária (INCRA), a partir de uma fusão do IBRA e do INDA. Neste momento, uma articulação entre o INCRA e o Programa de Integração Nacional (PIN) removeu camponeses dos focos de tensão no Nordeste levando-os para projetos de colonização na Amazônia. Além de minar a luta pela terra no Nordeste, o deslocamento de camponeses para Amazônia visou atender a escassez de mão de obra dos projetos agropecuários e de mineração na região. Portanto, a proposta do Estatuto da Terra possuía como plano de fundo a remoção de camponeses das áreas de tensão direcionando-os para novas áreas de colonização, o que se tratava de uma estratégia dos militares para desmobilizar o campesinato (Martins, 1981).

Destarte, os projetos de assentamentos da ditadura não tinham como centro a desapropriação dos latifúndios, mas sim, a distribuição de títulos de posse de terras, principalmente na Amazônia, aos agricultores despossuídos de terras. A política adotada pela ditadura militar era de proteção dos latifúndios e não de eliminação dos mesmos, pois a desapropriação de terras para a realização da reforma agrária ficou em segundo plano. Tratava-se de uma política a favor da preservação da concentração de terras e não da distribuição das mesmas através da reforma agrária.

As lutas tiveram sequência nos anos seguintes ao golpe, porém de forma isolada, localizada e com severas repressões e assassinatos de lideranças. A entrega de grandes extensões de terras a grupos empresariais nacionais e multinacionais foi realizada de forma intensa no governo militar.

No final da década de 1970 e início de 1980 o processo de modernização da agricultura expulsou milhares de camponeses, no entanto, o debate da reforma agrária estava abafado devido à forte repressão existente. Mas, a rebeldia dos camponeses, colocou novamente a reforma agrária na ordem do dia. As mobilizações populares continuaram e o fim da ditadura militar em 1985 reascendeu as esperanças de realização da reforma agrária, que apareceu como um dos compromissos prioritários do novo governo.

O I Plano Nacional de Reforma Agrária (PNRA) foi aprovado em 1985 e teve como base o Estatuto da Terra. A elaboração do plano contou com a presença de conhecidos defensores da reforma agrária como José Gomes da Silva, além de militantes sindicais, principalmente vinculados a Confederação Nacional dos Trabalhadores na Agricultura (CONTAG). É importante salientar que a Nova República buscou uma aproximação com a CONTAG, o que garantiu a esta organização papel de destaque junto às decisões a serem tomadas.

O I PNRA trouxe alguns retrocessos para a luta pela reforma agrária. Um deles é o artigo que expressava que se evitará sempre que possível a desapropriação dos latifúndios. Ganhou ênfase a negociação com os proprietários de terra em lugar da 
desapropriação. A utilização de terras públicas para assentamentos era outra característica presente no Plano que visava diminuir o peso político das desapropriações.

O Plano trazia ainda que as terras consideradas "produtivas" - mesmo que apenas uma parcela delas estivesse produzindo - não poderiam ser utilizadas para a reforma agrária, ou seja, a função social que a terra deveria atender para não ser desapropriada foi reduzida aos índices de produtividade. Dessa forma, não se levou em consideração os demais elementos relativos à função social da propriedade como, por exemplo, a violação dos direitos trabalhistas e a não preservação do meio ambiente, para a realização das desapropriações.

O Plano encontrou resistências junto às organizações populares, seus principais opositores foram o MST e a Central Única dos Trabalhadores (CUT). No mesmo dia que o Plano foi anunciado, o MST (neste momento localizado principalmente nos três estados do Sul do Brasil - Paraná, Santa Catarina e Rio Grande do Sul), realizou uma série de ocupações. A CONTAG, devido ao papel de destaque que havia no governo, apoiou a proposta do I PNRA.

As metas do Plano de reforma agrária previam o assentamento de 1.400 .000 famílias numa área de 43.090 .000 hectares no período correspondente entre 1985 a 1989. A apresentação do plano, somado às lutas do MST, provocou fortes manifestações dos latifundiários, que criaram a União Democrática Ruralista (UDR) em 1985. O principal objetivo da fundação da UDR era travar a reforma agrária e lutar contra o avanço dos movimentos camponeses, sobretudo do MST.

Em 1987, dois anos após a implantação do I PNRA, menos de $10 \%$ dos objetivos haviam sido alcançados. Neste período, com a queda de dois ministros da reforma agrária (Nelson Ribeiro e Dante de Oliveira) e morte em acidente de um terceiro (Marcos Freire), coube a Jader Barbalho assumir o Ministério da Reforma e do Desenvolvimento Agrário (MIRAD). Dentre os atos de Jader Barbalho no tempo em que ficou a frente do ministério (22 de setembro de 1987 a 29 de julho de 1988) está a extinção do INCRA e a criação do Instituto Jurídico de Terras Rurais (INTER). Além disso, baixou as metas do I PNRA de 1.400 .000 no período de 1985 a 1989 para 1.000.000 até 1991, bem como a área de assentamento destas famílias de 43.090.000 para 30.000.000 ha.

Diante destas medidas e de uma política de defesa dos interesses dos latifundiários, a organização dos camponeses e os conflitos no campo aumentaram. Os movimentos sociais e entidades de apoio articularam uma Campanha Nacional pela Reforma Agrária. A crescente organização culminou na luta travada no plenário do Congresso Nacional, durante a Constituinte em 1988.

Os ruralistas conseguiram incluir na constituição de 1988 um dispositivo que impedia a desapropriação de propriedades produtivas, além de firmar que aquelas desapropriadas deveriam ser feitas mediante prévia e justa indenização em Títulos da Dívida Agrária (TDAs) com a preservação do seu valor real. Novamente prevaleceu a política do latifúndio e o I PNRA foi enterrado. 
Os resultados do I PNRA foram de 89.950 famílias, não chegando a 7\% da meta estipulada, assentadas em uma área de 4,8 milhões de ha, ou seja, 1,5\% da área prevista para desapropriação. Além disso, os assentamentos foram realizados maiormente na região Norte como queriam os latifundiários, ou seja, protegendo os latifúndios do Sul e Sudeste onde as terras são mais "valorizadas" (Oliveira, 2007).

Em 1989 foi extinto o MIRAD. Neste mesmo ano foi recriado o INCRA, vinculado ao Ministério da Agricultura.

Em 1990, assumiu a presidência da república Fernando Collor de Melo do Partido da Reconstrução Nacional (PRN). Neste governo estipulou-se como meta, o assentamento de 500.000 famílias em quatro anos. Com o impeachment e a cassação de Collor, assumiu Itamar Franco (PRN), seu vice. Os assentamentos deste período de governo (1990-1994) não chegaram a 50.000 famílias. No governo de Itamar ainda, foi aprovada a "Lei Agrária" que regulamentava os dispositivos relativos à reforma agrária e o Rito Sumário que definiu os critérios para desapropriação de terras por interesse social. Através da "Lei Agrária" baniu-se a categoria latifúndio, substituindo-a por um critério menos politizado: o de módulos fiscais. A grande propriedade ficou compreendida como aquela que ultrapassasse os 15 módulos fiscais.

Em 1995, assumiu como presidente do Brasil, Fernando Henrique Cardoso (FHC) do Partido da Social Democracia Brasileira (PSDB). A política de não realização da reforma agrária e apoio aos setores latifundiários continuaram latentes. O novo governo não elaborou um plano de reforma agrária. Sua proposta se restringiu ao assentamento de 280 mil famílias nos quatro anos de seu mandato (1995-1998).

Neste período houve ascensão da luta pela terra em todo o país. O MST intensificou as ocupações e outros movimentos sociais e sindicais também adotaram a estratégia da ocupação e acampamento, como a CONTAG, por exemplo.

Por parte do governo, foram elaboradas medidas que visavam combater a principal ação dos camponeses que eram as ocupações de terra. Dentre as medidas tomadas estão: proibição de vistorias por um período de dois anos em imóveis que foram ocupados, suspensão das negociações em caso de ocupação de órgão público, criação da reforma agrária pelo correio e impossibilidade de acesso a recursos públicos por qualquer entidade que participasse ou apoiasse as ocupações de terra.

Estas medidas visavam desmobilizar os camponeses, principalmente, àqueles organizados no MST, considerado o principal opositor das políticas neoliberais do governo FHC. Realizou-se também uma verdadeira "satanização" do MST através de propagandas na mídia, produção de material de veiculação via internet, além de pesquisas de opinião pública sobre o Movimento. Estas ações tinham o objetivo de fazer desmoronar o apoio popular ao MST e à luta pela reforma agrária.

O governo procurou dividir os movimentos de luta pela reforma agrária, reconhecendo as demandas de alguns e ignorando de outros. O governo privilegiou os movimentos sociais ou sindicais moderados, que usavam da tática de negociação e não das 
ocupações de terra. $\mathrm{O}$ centro dessa política era o enfraquecimento da base social do MST.

Além disso, o governo Fernando Henrique criou o Projeto Cédula da Terra, base para outro programa, o Banco da Terra, que visava criar uma reforma agrária de mercado, apoiado nas propostas do Banco Mundial. Tratava-se de um modelo de reforma agrária "assistida pelo mercado", na qual, o Estado se incumbia somente do financiamento das transações imobiliárias entre os agentes privados (Pereira, 2006).

A reforma agrária "assistida pelo mercado" estava vinculada a um conjunto de políticas de "alívio" da pobreza no meio rural integrando um rol de compensações às políticas de ajuste do Banco Mundial (Pereira, 2006). No fundo a reforma agrária de mercado era a reforma pedida pelos latifundiários e grileiros, pois a desapropriação se dava pela compra da terra em dinheiro e a vista, ou seja, a renda da terra era repassada de uma só vez para as camadas latifundiárias.

Neste programa, para os camponeses terem acesso a terra, deveriam primeiramente constituir uma associação e atender a alguns requisitos, tais como: não possuir terras ou ser minifúndiário; ser chefes de família; maiores de idade; assumir o compromisso de devolver a quantia financiada. A associação deveria apresentar um proprietário que tivesse interesse em vender seu imóvel. A terra era negociada pelos beneficiários nos termos do mercado diretamente com o proprietário. O Estado repassava a condução do processo para os proprietários e beneficiários.

Ao programa de acesso à terra pelo mercado foram feitas severas críticas por estudiosos, movimentos sociais e sindicais, pois os latifundiários estavam sendo premiados. As terras improdutivas se tornaram verdadeiros ativos financeiros. $\mathrm{O}$ caráter punitivo da desapropriação defendido pelos movimentos camponeses, novamente foi deixado de lado em função de uma política que privilegiava o capital rentista.

Portanto, a reforma agrária de mercado não alterava as relações de força e poder na sociedade em favor do campesinato. Pois as transações patrimoniais financiadas pelo Estado nada tem a ver com uma reforma agrária redistributiva que ao distribuir terra ao campesinato pobre, também possui um caráter desapropriatório punitivo às terras que foram griladas do Estado ou que não cumprem sua função social (Pereira, 2006).

O segundo mandato de Fernando Henrique (1999-2002), novamente atendendo as políticas do Banco Mundial, procurou transformar os assentados em "agricultores familiares". Os camponeses foram considerados "empreendedores" e deveriam se ajustar ao mercado e aos negócios. Fez parte dessa proposta a rápida emancipação dos assentamentos, ou seja, em cerca de dois ou três anos após a demarcação das terras, os assentados eram considerados proprietários e o INCRA não teria mais obrigação de atendê-los como beneficiários da reforma agrária. A extinção do Programa de Crédito Especial para a Reforma Agrária (PROCERA) e o atendimento das famílias assentadas pelo Programa Nacional de Apoio à Agricultura Familiar (PRONAF), também fizeram parte deste conjunto de medidas. 
A reforma agrária ganhava assim, contornos meramente produtivistas e o mercado se tornava o regulador das relações entre os assentados. Além disso, se buscava eliminar o conteúdo político de luta e resistência presente nas manifestações dos camponeses.

A nefasta política de "contra-reforma agrária" de FHC, empregou ainda a violência para conter as lutas camponesas. O governo FHC foi marcado pelo uso da violência policial de forças estaduais na repressão aos camponeses sem terra como aquela cometida no massacre de Corumbiara em Rondônia e de Eldorado dos Carajás, no estado do Pará, além de assassinatos em vários estados brasileiros.

O campo brasileiro vivia neste período uma efervescência das lutas e os conflitos se acirravam entre camponeses, Estado e latifundiários. A resposta do governo FHC a estes conflitos foi o aumento da repressão policial. As forças policiais dos estados passaram a matar os camponeses em luta pela terra. Em contrapartida, no plano econômico, a política agrícola do governo prorrogou, infinitamente, as dívidas dos latifundiários (Oliveira, 2007). O governo FHC registrou novamente na história do campo brasileiro, o pacto do Estado com as elites latifundiárias e o desrespeito com os camponeses. Não realizava a reforma agrária, criminalizava os movimentos sociais e os tratava como caso de polícia.

Em 2003 com o primeiro mandato de Luís Inácio Lula da Silva (Partido dos Trabalhadores - PT), os camponeses acreditavam que a conquista da terra estava próxima, pois este presidente, historicamente comprometido com as lutas populares, havia garantido que a reforma agrária seria feita "numa canetada". No mesmo ano de 2003, uma equipe coordenada por Plínio de Arruda Sampaio elaborou uma proposta para o segundo Plano Nacional de Reforma Agrária. A proposta tinha como meta principal o assentamento de 1 milhão de famílias no período de 4 anos (2004 a 2007), seriam 200 mil famílias assentadas anualmente nos três primeiros anos e 400 mil no quarto ano.

Essa proposta foi desprezada pelo governo e o documento oficial aprovado para o II PNRA, teve como meta assentar 400.000 novas famílias (meta I) no período entre 2003 a 2006. Logo no primeiro ano se percebeu que o compromisso do governo não era com a reforma agrária. Os assentamentos criados ficaram aquém da meta estipulada de 30.000 famílias para este momento. Ainda, o INCRA e o Ministério do Desenvolvimento Agrário (MDA) divulgavam os dados de novos assentamentos (meta I), dados de regularização de posses (meta II) e os dados das demais metas de forma agrupada. Assim, como denunciou Oliveira (2007) o INCRA/MDA procurava inflacionar os números através da divulgação do dado - aliás, como já se fazia no governo FHC - total obtido através da Relação de Beneficiários (RBs). O INCRA considerava ainda, os dados de regularização fundiária e de reordenação de assentamentos antigos como novos assentamentos.

A divulgação dos dados acumulados criou uma falsa imagem de que a reforma agrária estava sendo realizada, no entanto, não se tratava de novas famílias tendo acesso a terra e nem de desconcentração fundiária. Sustenta-se que reforma agrária são ações resultantes da desapropriação de latifúndios, ou seja, uma reforma agrária real precisa mexer na estrutura fundiária do país e redistribuir as terras. 
Os dados da "reforma agrária" do governo Lula (2003-2010), revelam que efetivamente foram assentadas 151.968 novas famílias (Rodrigues, 2011). O governo Lula prosseguiu ainda com políticas de governos anteriores, preservando os latifúndios das regiões Sul, Sudeste e Centro-Oeste e criando assentamentos principalmente na região Amazônica. Assim, enquanto a maioria das famílias acampadas se concentrava no Centro-Sul do Brasil, região dominada pelo agronegócio/latifúndio, a maior parte delas foram assentadas na Amazônia.

Em 2011, no governo Dilma Rousseff (2011-2014), do Partido dos Trabalhadores (PT), foram assentadas pouco mais de 6.000 novas famílias. Além disso, o governo tem mudado o foco e a opção tem sido à "qualificação" dos assentamentos existentes. Ou seja, a reforma agrária com redistribuição de terras foi abandonada do projeto político do Estado, exemplo marcante é que o II PNRA acabou em 2007 e não foi elaborado um novo plano, tanto para o segundo mandato do governo Lula, quanto para o mandato da presidente Dilma.

\section{CONSIDERAÇÕES FINAIS}

Procurou-se ao decorrer do texto apresentar as lutas camponesas no Paraná e as suas conquistas, os assentamentos rurais, relacionando com as políticas de "reforma agrária" no Brasil. Evidenciou-se que no Paraná, assim como no Brasil, nunca houve uma efetiva política de reforma agrária. Os camponeses, diante de um quadro de expulsão e expropriação de suas terras e perante a conivência do Estado com a situação, se organizaram e começaram a pressionar o Estado para resolver o problema da concentração da terra. Os camponeses têm cobrado do Estado a solução para o monopólio da terra e posto na pauta política um projeto de desenvolvimento para o país que rompe com o latifúndio e com a monocultura. Ou seja, a "reforma agrária" brasileira tem sido feita pelos camponeses, pela sua teimosia, rebeldia, enfrentamento e resistência à expulsão e expropriação do campo e não por um programa de Estado.

Dentro deste contexto de enfrentamento, os camponeses tem tido algumas conquistas como é o caso da criação dos assentamentos rurais. No entanto, é preciso esclarecer que estes assentamentos não são decorrentes de um programa de reforma agrária, se trata de uma política de assentamento visando resolver os conflitos pela terra.

Por fim, concordamos com C. Kay (2007), que as principais causas da pobreza no meio rural estão umbilicalmente ligadas com a apropriação desigual da terra. A reforma agrária é, portanto, condição primordial para um desenvolvimento rural com equidade e melhoria da condição socioeconômica do campesinato. Agora, para que a reforma agrária tenha êxito é preciso a intervenção do Estado na redistribuição fundiária e no redesenho de um conjunto de políticas para atender a população camponesa. Portanto, se a propalada propaganda governamental de que "País Rico é País sem Miséria" quiser lograr sucesso, deverá se realizar uma verdadeira e inédita reforma agrária no Brasil. 


\section{BIBLIOGRAFIA}

BRASIL. Ministério do Desenvolvimento Agrário. II plano nacional de reforma agrária: paz, produção e qualidade de vida no meio rural. Governo Federal, 2003. 40 p.

BÓRON, Atílio. Estado capitalismo e democracia na América Latina. São Paulo: Paz e Terra, 1994.

COMISSÃO PASTORAL DA TERRA (CPT/PR). Desterro: uma cronologia da violência no campo no Paraná na década de 90. Curitiba, 2006. 152 p.

CONFRONTO entre sem-terra e agricultores deixa feridos. Folha de Londrina. Londrina, PR, p. 09, 01 de dez, 2006.

DATALUTA. Relatórios de Pesquisa. Presidente Prudente: São Paulo, NERA, 2006.

FABRINI, João Edmilson. Assentamentos de Trabalhadores Sem-Terra: Experiências e Lutas no Paraná. Marechal Cândido Rondon, PR: LGeo, 2001. 140 p.

FABRINI, João Edmilson. A resistência camponesa nos assentamentos de Sem Terra. Cascavel, PR: EDUNIOESTE, 2003. 275 p.

FABRINI, João Edmilson. Movimentos sociais no campo e outras resistências camponesas. In: PAULINO, Eliane T. e FABRINI, João E. (Orgs.) Campesinato e territórios em disputa. São Paulo, SP: Expressão Popular, 2008, p. 239-271.

FABRINI, João Edmilson. O campesinato frente à expansão do agronegócio e do agrocombustível. In: SAQUET, Marcos A. e SANTOS, Roseli A. dos (Orgs.). Geografia agrária, território e desenvolvimento. São Paulo, SP: Expressão Popular, 2010, p. 55-88.

FERNANDES, Bernardo M. MST: Movimento dos Trabalhadores Rurais Sem-Terra: formação e territorialização em São Paulo. São Paulo, SP: Hucitec, 1996. 285 p.

FERNANDES, Bernardo M. Questão agrária, pesquisa e MST. São Paulo, SP: Cortez, 2001. $120 \mathrm{p}$.

FERNANDES, Bernardo M. Entrando nos territórios do território. In: PAULINO, Eliane T. e FABRINI, João E. (Orgs.) Campesinato e territórios em disputa. São Paulo, SP: Expressão Popular, 2008, p. 273-301.

FERNANDES, Bernardo. M.; MARTIN, Jean. Y. Movimento socioterritorial e "globalização": algumas reflexões a partir do caso do MST. In: Lutas Sociais. São Paulo, PUC/ NERS, 2004, nº 11/12.

GRAZIANO NETO, Francisco. Recolocando a Questão Agrária: Plano de Reforma Agrária como Fruto de Uma Análise Equivocada. In: A Questão Agrária Hoje. Porto Alegre, RS: UFRGS, 1994. 
Instituto Nacional de Colonização e Reforma Agrária. Relatório dos assentamentos rurais paranaenses. Curitiba, Paraná, 2009. 20 p.

Instituto Brasileiro de Geografia e Estatística. Sinopse do censo demográfico 2010. 2010. Disponível em: <www.ibge.gov.br/sinopse>. [Acesso em: 20 jun. 2011].

KAY, Cristóbal. Pobreza rural en América Latina: teorias y estrategias de desarrollo. Revista Mexicana de Sociologia, jan-mar, 2007, vol. 69, $\mathrm{n}^{\circ}$ 01, p. 69-108.

MARQUES, Erwin Becker. A espacialização das ocupações de terra no estado do Paraná (1988-2006) e os limites da luta pela reforma agrária. 2008. 110 f. monografia (Graduação em Geografia) Centro de Ciências Humanas, Educação e Letras, Universidade Estadual do Oeste do Paraná, Marechal Cândido Rondon.

MARTINS, José de S. Os camponeses e a política no Brasil: as lutas sociais no campo e seu lugar no processo político. Petrópolis, RJ: Vozes, 1981. 185 p.

MEDEIROS, Leonilde Servolo de. Reforma Agrária no Brasil: História e Atualidade da Luta pela Terra. São Paulo, SP: Fundação Perseu Abramo, 2003. 103p.

MOURA, Margarida. M. Camponeses. 2a ed. São Paulo, SP: Ática, 1988. 78 p.

MST. A Reforma Agrária Necessária. São Paulo, SP: MST, 2006.

OLIVEIRA, Ariovaldo Umbelino de. A agricultura camponesa no Brasil. $2^{\mathrm{a}}$ ed. São Paulo, SP: Contexto, 1996. 164 p.

OLIVEIRA, Ariovaldo Umbelino de. Barbárie e Modernidade: As Transformações no Campo e o Agronegócio no Brasil. In: Terra Livre. São Paulo, jul/dez. 2003, ano 19, n $^{\circ}$ 21, p. 113-156.

OLIVEIRA, Ariovaldo Umbelino de. A Regularização Fundiária da MP 458 é a ContraReforma Agrária do Governo Lula. In: <www.radioagencianp.com.br $>$. [Acesso em: 10 de outubro de 2009].

OLIVEIRA, Ariovaldo Umbelino de. Modo de produção capitalista, agricultura e reforma agrária. São Paulo, SP: Labur Edições, 2007. 184 p.

OLIVEIRA, Ariovaldo Umbelino de. Geografia e os movimentos sociais. In: Perspectiva Geográfica. Marechal Cândido Rondon, PR: UNIOESTE, 2007, nº 3, p. 728.

Paraná. Instituto Paranaense de Desenvolvimento Econômico e Social. Leituras Regionais: mesorregiões geográficas paranaenses. Curitiba: IPARDES, 2004. Disponível em: <www.ipardes.gov.br>. [Acesso em: 15 maio 2011].

PEREIRA, João M. M. A política agrária do Banco Mundial em questão. Estudos Avançados, São Paulo, ago., 2006, vol. 20, nº 57, p. 355-383. 
RODRIGUES, Lúcia. Governo abandona de vez a reforma agrária. Caros Amigos, São Paulo, ed. 177, nov. 2011, p. 10-13.

ROOS, Djoni. $O$ aprendizado e resistência camponesa nos acampamentos $e$ assentamentos de Sem-Terra em Quedas do Iguaçu/PR. 2010. 182 f. Dissertação (Mestrado em Geografia), Centro de Ciências Humanas, Universidade Estadual do Oeste do Paraná, Francisco Beltrão.

SILVA, José Graziano da. Caindo por Terra: Crises da Reforma Agrária na Nova República. São Paulo, SP: Busca Vida, 1987. 228 p.

(C) Copyright Djoni Roos, 2013.

(C) Copyright GeoGraphos, 2013.

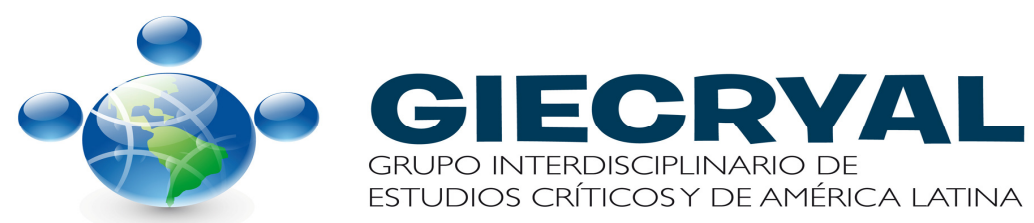

